\title{
Impacts of urbanization on land-atmosphere carbon exchange within a metropolitan area in the USA
}

\author{
Jeremy E. Diem*, Catherine E. Ricketts, John R. Dean \\ Department of Geosciences, Georgia State University, PO Box 3998, Atlanta, Georgia 30302-3998, USA
}

\begin{abstract}
Urbanization can cause changes in carbon fluxes, which, in turn, impacts atmospheric carbon dioxide $\left(\mathrm{CO}_{2}\right)$ concentrations and possibly global surface temperatures. Using the Atlanta, Georgia, region as a case study, this paper explores the impact of urban expansion from 1973 to 2002 on land-atmosphere carbon exchange. The major objectives were to estimate net ecosystem production (NEP) values for multiple land-cover classes and to link urbanization-induced changes in land-cover to changes in NEP and overall carbon fluxes. The principal data were daily climatic data, year-specific land-cover data, annual net ecosystem exchange (NEE) values, and annual anthropogenic carbon emissions estimates. The principal methods were testing for climatic trends, determining the composition of the land-cover classes, estimating annual NEP values for the land-cover classes, and estimating the overall carbon exchange. The major findings: (1) there were no significant trends for any of the climatic variables; (2) the region was only 16\% urbanized in 1973 ; however, by 2002 , the region was $\sim 38 \%$ urbanized; (3) the NEP in $1978-1980$ of $443 \mathrm{~g} \mathrm{C} \mathrm{m}^{-2} \mathrm{yr}^{-1}$ may have continued until 1996-1998, despite the substantial loss of forest land; and (4) net carbon emissions increased from $\sim 150 \mathrm{~g}$ in 1978-1980 to $\sim 940 \mathrm{~g} \mathrm{C} \mathrm{m}^{-2} \mathrm{yr}^{-1}$ in 1996-1998. Therefore, urban expansion greatly increased the carbon emissions of the Atlanta region; however, it is possible that, through increasing the growing-season length as well as increasing nitrogen and $\mathrm{CO}_{2}$ fertilization, urban expansion may not decrease the region-wide NEP.
\end{abstract}

KEY WORDS: Net ecosystem production $\cdot$ NEP $\cdot$ Net ecosystem exchange $\cdot$ NEE $\cdot$ Urban emissions Carbon $\cdot$ Carbon dioxide $\cdot \mathrm{CO}_{2}$

\section{INTRODUCTION}

The effects of urbanization on land-atmosphere carbon exchange are not well understood. Local-scale activities in metropolitan areas can contribute to environmental changes at larger geographic scales (Wilbanks \& Kates 1999). For instance, local perturbations of the carbon cycle should theoretically impact atmospheric concentrations of the greenhouse gas carbon dioxide $\left(\mathrm{CO}_{2}\right)$ globally. From 1973 to 2002, atmospheric $\mathrm{CO}_{2}$ concentrations increased $13 \%-$ mean annual atmospheric $\mathrm{CO}_{2}$ concentrations at remote locations were 329 and 373 ppm in 1973 and 2002, respectively (Keeling \& Whorf 2005). Increased $\mathrm{CO}_{2}$ concentrations - through increases in net radiative energy available to the Earth-atmosphere system - may have caused hemispheric and global temperatures to rise over the past $30 \mathrm{yr}$ (IPCC 2001). Some researchers have argued that Northern Hemisphere warming has been confined mostly to cold, dry air masses that are centered over Siberia and northwestern North America during the winter season (Michaels et al. 2000). Within the past $30 \mathrm{yr}$, warming in the northern high latitudes may be responsible for increased plant growth (Myneni et al. 1997) and accelerated ice-sheet melting in those areas (Vinnikov et al. 1999). Through changes in land cover and land use, urbanization can influence global atmospheric $\mathrm{CO}_{2}$ concentrations, which can, in turn, impact geographically distant regions, such as polar and subpolar regions.

One way that land-cover modifications, such as urbanization, can impact global atmospheric $\mathrm{CO}_{2}$ 
concentrations is through changes in net ecosystem production (NEP). NEP can be defined as follows:

$$
\mathrm{NEP}=\mathrm{GPP}-\left(\mathrm{R}_{\mathrm{a}}+\mathrm{R}_{\mathrm{h}}\right)
$$

where GPP is gross primary production, $R_{a}$ is autotrophic respiration (i.e. respiration by vegetation) and $\mathrm{R}_{\mathrm{h}}$ is heterotrophic respiration (e.g. soil microbial respiration). NEP is measured using biometric methods (i.e. ecological-inventory technique; Barford et al. 2001, Curtis et al. 2002). NEP is similar to net primary production (NPP), with the major disparity being that $\mathrm{R}_{\mathrm{h}}$ is not used in the calculation of NPP (i.e. NPP = GPP $-R_{a}$ ). NEP is equivalent to net ecosystem exchange (NEE), with NEE having a negative value if NEP has a positive value. NEE is measured using the eddy-covariance method, which employs towermounted instruments to measure trace gas flux densities between the biosphere and the atmosphere (Baldocchi et al. 1996). The longitudinal dimensions of flux footprints for eddy-covariance towers range from $100 \mathrm{~m}$ to several $\mathrm{km}$ (Schmid 1994), thus flux values are applicable only at the local scale.

\subsection{Potential impacts of urbanization on NEP}

There are multiple ways that urbanization can decrease NEP. The principal way in non-arid regions is through deforestation. Urbanization in the USA may reduce NPP by $\sim 0.4 \mathrm{Pg} \mathrm{Cyr}^{-1}$ (Imhoff et al. 2004). Other negative impacts of urbanization on NEP are related to changes in composition and temperature of the troposphere (i.e. lowest layer of the atmosphere). Urban aerosols can scatter and absorb more photosynthetically active radiation (PAR) than continental/rural aerosols (Erlick \& Frederick 1998). Urban aerosols should diminish PAR within and downwind of urban areas, and the decrease in PAR might reduce photosynthesis (i.e. GPP) in the affected areas. For example, in Athens, Greece, highly polluted urban sites have been shown to have $18 \%$ less PAR than less-polluted rural sites (Jacovides et al. 1997). In addition to aerosols, urban areas also are major sources of ozoneprecursor chemicals, and the highest ozone levels in the USA typically occur within and downwind of large metropolitan areas (US EPA 2004). Increased levels of ground-level ozone, an atmospheric pollutant, cause foliar injury to sensitive species and can reduce photosynthesis by $>25 \%$ (Novak et al. 2005). Ground-level ozone may reduce the amount of carbon sequestration in the USA by up to $0.04 \mathrm{Pg} \mathrm{yr}^{-1}$ (Felzer et al. 2004). Finally, urbanization may cause an increase in the heterotrophic decomposition of soil organic matter, because this form of respiration is positively correlated with soil temperature (Davidson et al. 1998). A typical city has an associated urban heat island (UHI), characterized by temperatures up to $12^{\circ} \mathrm{C}$ higher than temperatures at nearby rural areas (Oke 1987). Therefore, increased soil temperatures caused by the UHI should, in turn, increase soil $\mathrm{CO}_{2}$ fluxes.

Urbanization may also increase NEP. Since the UHI increases temperatures, it can cause an increase in growing-season length (GSL). As a result, a $1 \mathrm{~d}$ increase in GSL may increase NEP by $1.6 \%$ (White et al. 1999). For the eastern USA, the GSL for urban areas is 1 to $3 \mathrm{wk}$ longer than that of rural areas: White et al. (2002) found that urban areas have a GSL that is $~ 8 \mathrm{~d}$ longer than that of deciduous forest areas, with most of the increase occurring at the start of the season, and Zhang et al. (2004) found a GSL difference between urban and rural areas of $15 \mathrm{~d}$ for the entire eastern USA. Urban areas may have more fertile soils than rural, forested areas, because of higher nitrogen loads from fertilizer use (Groffman et al. 2004) and there are increased rates of nitrogen deposition within and downwind of urban areas (Lovett et al. 2000, Fenn et al. 2003). For example, nitrogen deposition may be responsible for an additional $0.15 \mathrm{Pg} \mathrm{C} \mathrm{yr}^{-1}$ of carbon sequestration within the continental USA (from Fig. 4a in Townsend et al. 1996). Elevated $\mathrm{CO}_{2}$ concentrations can increase NPP (Friedlingstein et al. 1995). Urban $\mathrm{CO}_{2}$ concentrations can be approximately $30 \%$ higher than rural $\mathrm{CO}_{2}$ concentrations (Idso et al. 2001), and even during the summer-when photosynthesis is maximized-urban $\mathrm{CO}_{2}$ concentrations can exceed 450 ppm (Aikawa et al. 1995, Takagi et al. 1998, Gratani \& Varone 2005). Soil-nitrogen levels can limit $\mathrm{CO}_{2}$ fertilization of vegetation (Oren et al. 2001), but soil nitrogen levels in urban areas may be sufficiently high to prevent this limitation from occurring. Concerning solar radiation and diffuse PAR, urban aerosols may increase photosynthesis. When the proportion of diffuse PAR increases as part of total PAR at the expense of direct radiation, increased photosynthesis is the likely result due to a reduced volume of shade (Roderick et al. 2001) and greater light-use efficiency with fewer leaves experiencing light saturation (Misson et al. 2005). For example, at a coniferous forest site in rural California, the advection of urban aerosols to the site decreased total PAR by $10 \%$ yet increased diffuse PAR by $24 \%$; consequently, the net effect was an $8 \%$ increase in NEE (Misson et al. 2005).

Two field studies in the eastern USA found urban productivity to be greater than rural productivity. For first-year vegetation regrowth (e.g. lambsquarters Chenopodium album) on previously fallow land in the Baltimore (Maryland, USA) area, Ziska et al. (2004) found that by the end of the growing season aboveground biomass at an urban site was $115 \%$ higher than that at a rural site. Similarly, Gregg et al. (2003) 
reported that Eastern cottonwood Populus deltoides grown in urban areas in New York City had twice as much biomass as the same trees grown in nearby rural areas. Both studies found that the urban atmosphere differs from the rural atmosphere. For example, Gregg et al. (2003) found that in urban areas (1) atmospheric $\mathrm{CO}_{2}$ concentrations were up to $15 \%$ higher; (2) nitrogen deposition was significantly higher; (3) aerosol concentrations were up to $200 \%$ higher; and (4) tropospheric ozone levels were up to $40 \%$ lower. Additionally, the frost-free period (FFP) was at least several weeks longer at the urban Baltimore site than at the rural site (Ziska et al. 2004). As noted in Gregg et al. (2003), it is possible that there was no enhanced growth in urban areas; rather, suppressed growth in rural areas may have been caused by increased ozone exposure. Neither study examined the potential impact of increased diffuse PAR in urban areas on vegetation growth.

Regional changes in GSL, solar radiation, and soil moisture exert strong controls over NEP, thus climatic variability at larger spatial scales can confound urban effects (i.e. local and mesoscale impacts) on NEP. In the absence of urban effects, interannual variability of land-atmosphere $\mathrm{CO}_{2}$ exchange can be large: over a 9 yr period at a northern hardwood forest, annual NEE ranged from -120 to $-250 \mathrm{~g} \mathrm{C} \mathrm{m}^{-2} \mathrm{yr}^{-1}$ (Barford et al. 2001); over a $5 \mathrm{yr}$ period at a mixed temperate deciduous forest, annual NEE ranged from -470 to $-629 \mathrm{~g}$ $\mathrm{C} \mathrm{m}^{-2} \mathrm{yr}^{-1}$ (Wilson \& Baldocchi 2001); and over a $3 \mathrm{yr}$ period at a northern mixed hardwood forest, NEP estimates ranged from 80 to $170 \mathrm{~g} \mathrm{C} \mathrm{m}^{-2} \mathrm{yr}^{-1}$ (Schmid et al. 2003). Large changes in annual gross ecosystem exchange (GEE) - which is similar to GPP - at northern hardwood forests can be associated with modest changes in GSL (Goulden et al. 1996). GSL for deciduous forests in the eastern USA is highly variable from year to year, and a $2 \mathrm{wk}$ change in GSL typically causes a $9 \%$ change in NEP (White et al. 1999). Increased cloudiness (leading to decreased solar radiation) during summer can cause decreased NEP; prolonged periods of cloudiness during mid-July 1992, mid-August 1992, and August 1994 each reduced GPP at a northern hardwood forest by approximately $40 \mathrm{~g} \mathrm{C} \mathrm{m}^{-2}$ (Goulden et al. 1996). Finally, since drought leads to dry surface soil and thus decreased ecosystem respiration, NEP can increase during dry summers (Goulden et al. 1996, Barford et al. 2001).

\subsection{Research objectives}

The present study sought to ascertain how far urban expansion has impacted land-atmosphere carbon exchange within a metropolitan area. No published studies exist that provide either theoretical or empirical exami- nations of the impacts of urban expansion on exchanges of carbon between the biosphere and atmosphere. Multiple studies have examined either atmospheric $\mathrm{CO}_{2}$ concentrations or $\mathrm{CO}_{2}$ fluxes (e.g. Aikawa et al. 1995, Takagi et al. 1998, Idso et al. 2001, Takahashi et al. 2001, Grimmond et al. 2002, 2004, Nemitz et al. 2002, Kuc et al. 2003, Pataki et al. 2003, Moriwaki \& Kanda 2004, Gratani \& Varone 2005) in urban areas. In addition, at least 2 studies (Milesi et al. 2003, Imhoff et al. 2004) have estimated the impacts of urbanization on NPP. Although several studies (e.g. Koerner \& Klopatek 2002, Soegaard \& Møller-Jensen 2003) have explored differences in $\mathrm{CO}_{2}$ fluxes between land-cover types within a metropolitan area, they do not link urban expansion and land-atmosphere carbon exchange. Investigations of carbon exchanges within a metropolitan area are vitally important, because the urban ecosystem contains invaluable information on the carbon cycle, especially the controls and impacts of its associated processes in the context of land-cover change and climatic variability.

The objectives of the study were (1) to establish baseline NEP values for land-cover classes within a metropolitan area over a 30 yr period, (2) to quantify the impact of land-cover changes and the UHI on NEP values, and (3) to assess temporal changes in overall land-atmosphere carbon exchange.

\subsection{Study region}

The Atlanta region (i.e. the innermost 13 counties of the Atlanta metropolitan statistical area, with an area of $10433 \mathrm{~km}^{2}$ ) in the southeastern USA (Fig. 1) was selected because (1) metropolitan Atlanta has undergone massive population and land-cover changes over the past few decades and (2) actual NEE measurements have been made at multiple sites in the southeastern USA. The population of the Atlanta region increased from 1.57 million in 1970 to 3.7 million in 2000, and the annual growth rate in the 1980s and 1990s was larger than the growth rate in the 1970s (US Census Bureau 2001). This growth was associated with tremendous suburban sprawl and the loss of a substantial amount of forest land (Yang \& Lo 2002). Since NEE measurements via the eddy-covariance technique are available for 2 locales (Walker Branch Watershed and Duke Forest) in the southeastern USA (Fig. 1), carbon fluxes can be inferred for the Atlanta region. With Walker Branch Watershed and Duke Forest located only 175 and $400 \mathrm{~km}$ from the Atlanta region, respectively, and with none of the locales being situated at high elevations or in complex terrain, all 3 locales have humid subtropical climates (Trewartha \& Horn 1980). Moreover, the 3 locales have similar climatic constraints to plant growth (from Fig. 1a in Nemani et al. 2003). Concerning land 


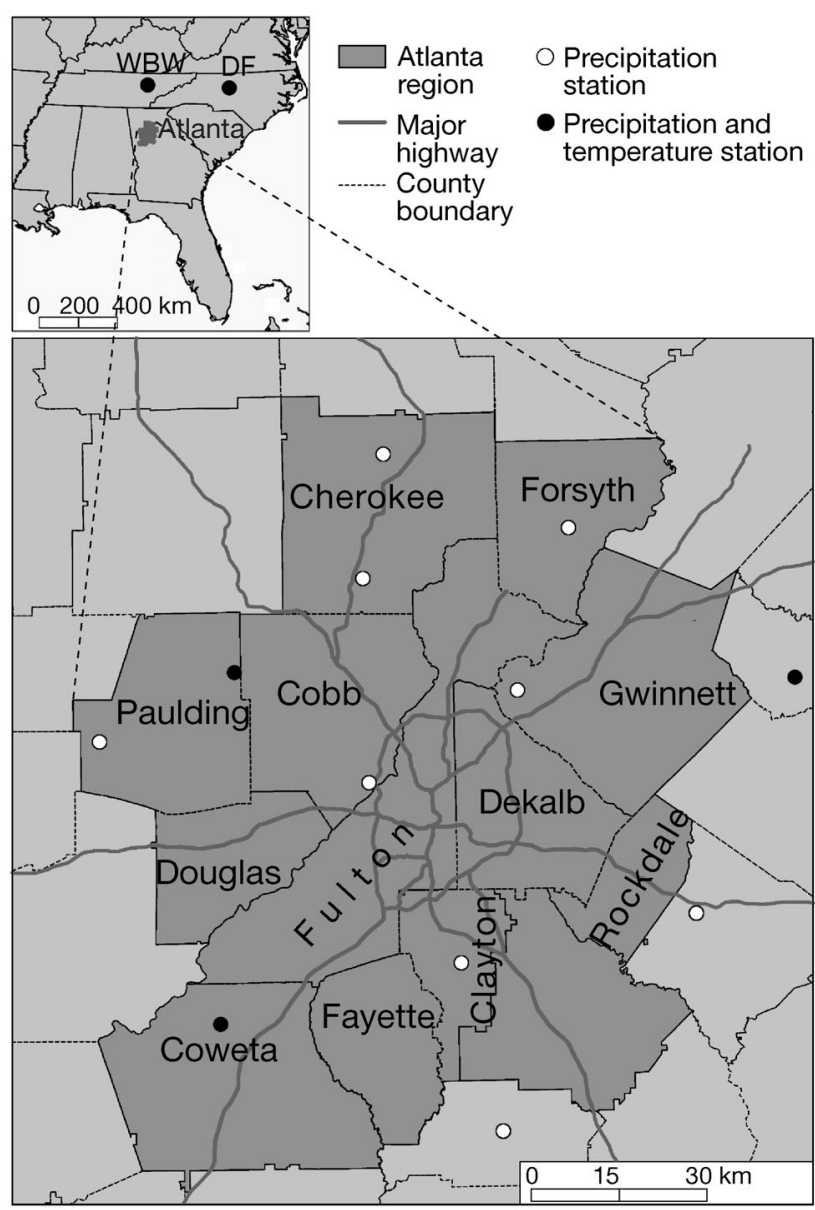

Fig. 1. The 13-county Atlanta region, locations of temperature and precipitation stations within and adjacent to the region, and locations of Atlanta region and 2 eddy-covariance sites (WBW: Walker Branch Watershed; DF: Duke Forest)

cover, forested areas in the Atlanta region are equivalent to either the vegetation at Walker Branch Watershed or Duke Forest or both; using the International Geosphere-Biosphere Programme global vegetation classification scheme, Atlanta-region forests are classified as either mixed forest or deciduous broadleaf forest, Walker Branch Watershed is classified as deciduous broadleaf forest, and Duke Forest is classified as mixed forest (see the FLUXNET Project, Oak Ridge National Laboratory Distributed Active Archive Center; available at www-eosdis.ornl.gov/FLUXNET/).

\section{DATA AND METHODS}

\subsection{Land cover}

Moderate-resolution land-cover data for 1973, 1979, 1983, 1987, 1992 and 1997 for the Atlanta region-as described in Yang \& Lo (2002) - were obtained from
Landsat satellite imagery (i.e. thematic mapper and multispectral scanner) ${ }^{\mathbf{1}}$; the spatial resolution ranged from $\sim 30$ to $\sim 80 \mathrm{~m}$. All years except 1987 and 1997 had the following core land-cover categories: high-density urban land, low-density urban land, barren land, grass/crops, forest, and water (see Yang \& Lo 2002). 1987 and 1997 had 3 forest classes (i.e. coniferous forest, deciduous forest, and mixed forest) and an additional grassland class (i.e. golf course). Land-cover proportions were generated for every year from 19732002; proportions were interpolated using the inversedistance weighting (IDW) method for the following sets of years: 1974-1978, 1980-1982, 1984-1986, 19881991, and 1993-1996, while land-cover proportions were extrapolated for 1998-2002 using the rate of change of land cover from 1992 to 1997.

The percent coverage of construction materials, exposed rock, exposed soil, grass/crops, trees/shrubs, and water for the land-cover classes were estimated through the use of $1 \mathrm{~m}$ resolution, multi-spectral digital ortho photo quad quarters (DOQQs) from 1999² . The 9 landcover classes for the 1997 classification were assessed. Approximately 30 groups of pixels per land-cover class were selected randomly throughout the Atlanta region.

\subsection{Regional climate}

Daily temperature data from 1972-2002 were obtained for 5 stations in the southeastern USA. Daily maximum and minimum temperatures for 3 stations (Dallas 7 NE, Newnan 4 NE, and Winder $1 \mathrm{SSE}$ ) within or proximate to the Atlanta region as well as for 1 station in North Carolina (Chapel Hill 2 W) and another station in Tennessee (Oak Ridge ADTL) were obtained ${ }^{\mathbf{3}}$. Since none of the temperature measurements were made in urban areas, it was assumed that the UHI had little impact on temperature values at any of the stations. Daily minimum temperatures were used to determine the last spring-freeze date and the first fallfreeze date for each year; the number of days between these dates is the FFP, which is a proxy for GSL (e.g. Robeson 2002). In addition, the mean of the minimum and maximum daily temperatures was used to determine cumulative thermal summation for each year. This was employed to estimate the date on which the growing season began, using the following information: (1) start date (i.e. mean date over the 1973-2002 period on which the lowest mean daily temperature occurred); (2) daily positive deviations from $15^{\circ} \mathrm{C}_{i}$ (3) summed de-

\footnotetext{
${ }^{1}$ Data obtained from C. P. Lo of the University of Georgia 2Data provided by the Georgia GIS Data Clearinghouse ${ }^{3}$ Data obtained from the TD3200 database of the National Climatic Data Center (NCDC)
} 
viations (from 2, above) for each year; (4) end date (i.e. mean date over the 1973-2002 period on which the last spring freeze occurred); and (5) critical thermal summation value (i.e. mean value for the $30 \mathrm{yr}$ period) (see Hunter \& Lechowicz 1992, White et al. 1997).

Monthly precipitation totals from 1972 to 2002 for 13 stations within or proximate to the Atlanta region (Fig. 1) were calculated ${ }^{4}$. Daily totals were summed to yield monthly precipitation totals. For all months with $<20 \%$ missing daily values, monthly precipitation totals were multiplied by the ratio of days per month divided by the number of days with valid data. If any month had $>20 \%$ of missing daily values, the precipitation total was estimated using an IDW scheme involving data from at least 3 nearby stations. Only $2 \%$ of the monthly totals needed to be estimated using the IDW method.

Mean daily solar radiation estimates for all months from 1961-1990 were obtained ${ }^{5}$. In order to extrapolate the solar radiation values to 2002, the Bermuda High Index (BHI) was constructed and precipitation days were determined. The BHI is a measure of the slope of the sea level pressure (SLP) gradient between Bermuda and New Orleans (Louisiana, USA) and is positively correlated to precipitation - and, by extension, cloudiness - over the southeastern USA during all seasons (Stahle \& Cleaveland 1992, Henderson \& Vega 1996). Monthly SLP at grid points corresponding to Bermuda $\left(32.33^{\circ} \mathrm{N}, 64.75^{\circ} \mathrm{W}\right)$ and New Orleans $\left(29.95^{\circ} \mathrm{N}, 90.10^{\circ} \mathrm{W}\right)$ were used to construct the BHI ${ }^{\mathbf{6}}$. Standardized monthly SLP at New Orleans was subtracted from standardized monthly SLP at Bermuda (Stahle \& Cleaveland 1992). Daily precipitation totals for the southern and northern sides of the Atlanta metropolitan area from 1961 to 2002 were obtained ${ }^{7}$. The frequency of precipitation days per month was calculated. Only $1 \%$ of the months had incomplete data, and precipitation-day frequencies for nearby stations with complete data were used for those months. Multiple linear regression models with the BHI and precipitation-day frequency as the initial predictor variables were used to predict mean daily solar-radiation values for all months for the 1991-2002 period.

Temporal variability and trends in solar radiation, temperature, precipitation, and FFP for the Atlanta region were assessed for the following groups of months: November-October, April-October, and June-July. NEE

\footnotetext{
4Data derived from the NCDC's TD3200 database

${ }^{5}$ Data obtained from the National Solar Radiation Database for Hartsfield-Jackson Atlanta International Airport $\left(33.65^{\circ} \mathrm{N}\right.$, $84.43^{\circ} \mathrm{W}$ )

${ }^{6}$ Data extracted from the NCEP/NCAR Reanalysis database (Kalnay et al. 1996), Climate Diagnostics Center of NOAA and Cooperative Institute for Research in Environmental Sciences ${ }^{7}$ Data from the NCDC's TD3200 database (Stns Newnan and Norcross)
}

for southeastern forests is maximized during the AprilOctober period (see Falge et al. 2002a). Since NEE peaks in June at Walker Branch Watershed and in July at Duke Forest, the June-July period represents the peak of the growing season. The November-October period includes not only the growing season but also conditions antecedent to the growing season. The magnitude of interannual variability was expressed with the coefficient of variation, while significant trends were determined with the Spearman rank-order correlation test (2-tailed, $\alpha=0.05)$. Finally, the years that were most similar with respect to regional climate (i.e. solar radiation, temperature, precipitation, and GSL) were targeted for an analysis of urbanization impacts on GSL and, in turn, NEP.

\subsection{Carbon fluxes}

NEE data for either the late 1990s or early 2000s were obtained for a deciduous forest at Walker Branch Watershed near Oak Ridge, Tennessee, and coniferous forests and grassland at Duke Forest near Chapel Hill, North Carolina. The Walker Branch Watershed site $\left(35.96^{\circ} \mathrm{N}, 84.29^{\circ} \mathrm{W}\right)$ was dominated by oak (Quercus sp.), maple (Acer sp.), and tulip poplar Liridodendron tulipifera (Wilson \& Baldocchi 2001). The Duke Forest coniferous sites $\left(35.97^{\circ} \mathrm{N}, 79.08^{\circ} \mathrm{W} ; 36.03^{\circ} \mathrm{N}, 79.13^{\circ} \mathrm{W}\right)$ were almost entirely covered by loblolly pine Pinus taeda (Hamilton et al. 2002, Lai et al. 2002, Schäfer et al. 2003). The Duke Forest grassland site $\left(35.97^{\circ} \mathrm{N}\right.$, $79.09^{\circ} \mathrm{W}$ ) was a field covered with tall fescue Festuca arundinaria (Novik et al. 2004). Walker Branch Watershed NEE values from 1998 and 1999 were -610 g C $\mathrm{m}^{-2} \mathrm{yr}^{-1}$ (see Wilson \& Baldocchi 2001). Duke Forest coniferous NEE values from 1998 and 1999 were $-492 \mathrm{~g}$ $\mathrm{C} \mathrm{m}{ }^{-2} \mathrm{yr}^{-1}$ (see Hamilton et al. 2002, Lai et al. 2002, Schäfer et al. 2003). Duke Forest grassland NEE values from 2001 were $-65 \mathrm{~g} \mathrm{C} \mathrm{m}^{-2} \mathrm{yr}^{-1}$ (see Novik et al. 2004).

The NEE values from Walker Branch Watershed and Duke Forest were used to estimate NEP for the 6 landcover classes in the Atlanta region. For example, if a land-cover class was entirely deciduous forest, it would receive an NEP value of $610 \mathrm{~g} \mathrm{C} \mathrm{m}^{-2} \mathrm{yr}^{-1}$. Baseline NEP values were generated by taking into account differences in GSL between the Atlanta region and the region in which NEE was measured. For deciduous forests in the eastern USA, a $1^{\circ} \mathrm{C}$ increase in mean annual temperature is associated with an $5 \mathrm{~d}$ increase in GSL, causing NEP to increase by $8 \%$ (White et al. 1999). It was assumed that NEE values for coniferous forests would increase at the same rate.

UHI impacts on NEP were estimated for years with similar regional atmospheric conditions. In order to adjust the GSL and NEP values for UHI-impacted pixels in the Atlanta metropolitan area, the following pro- 
Table 1. Urban heat island-based scenarios for adjustment of net ecosystem production (NEP). GSL: growing-season length

\section{Description}

1 No urban adjustment

2 Urban-core zone and urban-buffer zone were based only on high-density urban pixels

All pixels in the urban-core zone received a $15 \mathrm{~d}$ GSL adjustment

All pixels in the urban-buffer zone received a $10 \mathrm{~d}$ GSL adjustment

Individual high-density urban pixels outside the zones received a $15 \mathrm{~d}$ GSL adjustment

3 Urban-core zone and urban-buffer zone were based on both high-density and low-density urban pixels All pixels in the urban-core zone received a $15 \mathrm{~d}$ GSL adjustment

All pixels in the urban-buffer zone received a $10 \mathrm{~d}$ GSL adjustment

Individual high-density urban pixels outside the zones received a $15 \mathrm{~d}$ GSL adjustment

4 Urban-core zone and urban-buffer zone were based on both high-density and low-density urban pixels

All pixels in the urban-core zone received a $15 \mathrm{~d}$ GSL adjustment

All pixels in the urban-buffer zone received a $10 \mathrm{~d}$ GSL adjustment

Individual high-density urban pixels outside the zones received a $15 \mathrm{~d}$ GSL adjustment

Individual low-density urban pixels outside the zones received a $15 \mathrm{~d}$ GSL adjustment

cedures were performed (see Zhang et al. 2004): (1) the land-cover data were coarsened to $1 \mathrm{~km}$ resolution; and (2) urban-core zones were identified and then buffered to produce zones 2.4 times larger in area than the initial urban-core zones. It was assumed that the urban-core zones had an increased GSL of $15 \mathrm{~d}$ and the buffer zones (i.e. areas adjacent to the urban core) had an increased GSL of $10 \mathrm{~d}$. The different UHI-based NEP-adjustment scenarios are described in Table 1.

Additional emissions data and $\mathrm{CO}_{2}$ concentration data were used to enhance carbon-flux estimates for the Atlanta region. Annual county-level estimates of nitrogen oxides $\left(\mathrm{NO}_{\mathrm{x}}\right)$ and particulate matter $\left(\mathrm{PM}_{10}\right)$ emissions from 1985 to 1999 were obtained ${ }^{\underline{8}}$. Statelevel estimates of annual anthropogenic carbon emissions from 1960 to $2001^{\underline{9}}$ included all sources except cement manufacture, gas flaring, bunker fuels, and human respiration. Carbon-emission estimates for the Atlanta region were obtained by multiplying statewide carbon emissions by the ratio of the Atlanta-region $\mathrm{NO}_{\mathrm{x}}$ emissions to the statewide $\mathrm{NO}_{\mathrm{x}}$ emissions.

${ }^{8}$ Data from the US Environmental Protection Agency's AirData website (www.epa.gov/air/data)

${ }^{9}$ Data from the Carbon Dioxide Information Analysis Center of Oak Ridge National Laboratory

\section{RESULTS}

\subsection{Land cover}

The Atlanta region underwent massive changes in urban and forest land cover during the 1973-2002 period (Fig. 2). High-density urban land increased from 4.3 to $8.3 \%$; low-density urban land increased from 11.6 to $29.1 \%$; barren land increased from 1.0 to $2.2 \%$; grassland/cropland decreased from 19.0 to $12.0 \%$; forest decreased from 62.6 to $45.7 \%$; water surface increased from 1.5 to $2.5 \%$. Overall urbanization increased from 16 to $38 \%$.

The land-cover classes were made up as follows:

- high-density urban was almost entirely construction materials

- barren land class was either exposed soil or rock

- grassland/cropland was almost entirely grass/ crops

- water was entirely water

- forest was $50 \%$ deciduous trees and $50 \%$ coniferous trees

- low-density urban was $43 \%$ grass, $34 \%$ trees/ shrubs, and $23 \%$ construction materials (for trees/ shrubs it was assumed that the deciduous/coniferous ratio was the same as for the forest class).

\subsection{Regional climate}

There were no significant trends for any of the 12 climatic variables over the 1973-2002 period; however, some of the variables had considerable interannual variability (Fig. 3). Coefficients of variation ranged from 3 to $41 \%$ for the climatic variables, with precipitation (especially summer precipitation) and temperature having the highest and lowest interannual vari-

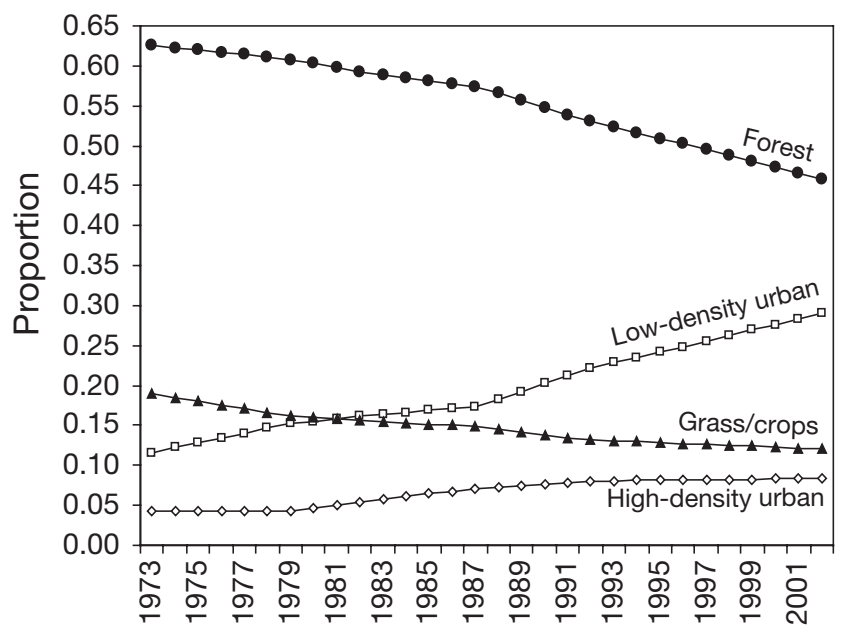

Fig. 2. Time series of changes in cover within the Atlanta region. Remaining land-cover classes (i.e. barren land and water) collectively covered $<5 \%$ of the area 

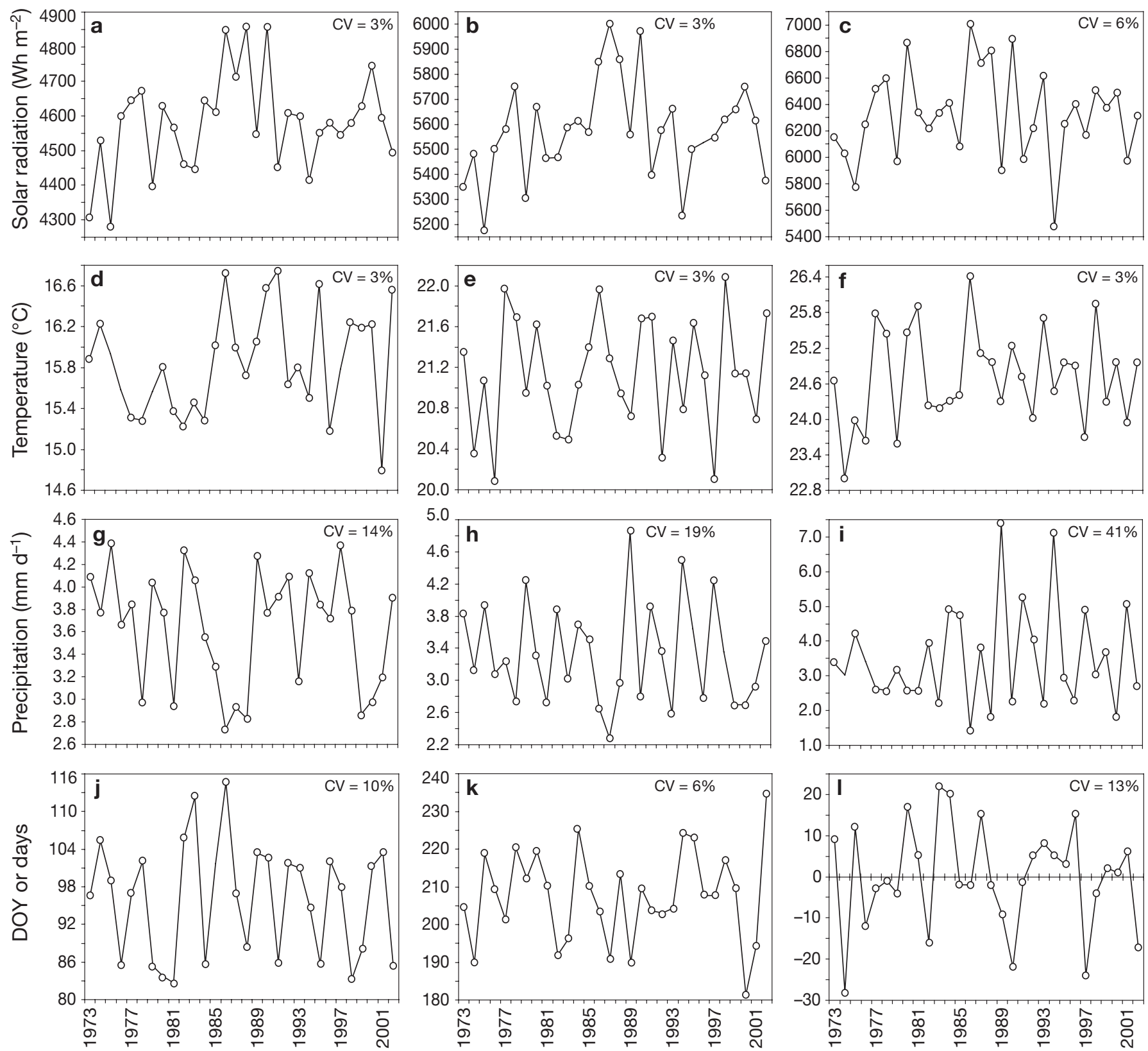

Fig. 3. Time series of $(\mathrm{a}-\mathrm{c})$ mean daily solar radiation for November-October, April-October, and June-July, respectively; $(\mathrm{d}-\mathrm{f})$ mean daily temperature for April-October, June-July, and November-October, respectively; (h,i) mean daily precipitation for April- October, and June-July, respectively; (j) last spring-freeze date (day of year [DOY]); (k) frost-free period (in days); and (l) deviation from estimated typical start of growing season based on cumulative thermal summation (in days). CV: coefficient of variation. Note scale differences on $y$-axes

ability, respectively. Two periods that had similar climatic conditions were 1978-1980 and 1996-1998 (Table 2); thus impacts of land cover on changes in NEP from $\sim 1979$ to $\sim 1997$ could be assessed directly. Both periods had approximately normal values for solar radiation, temperature, precipitation, last springfreeze date, first fall-freeze date, FFP, and deviation from the estimated typical start of the growing season.
Since solar-radiation predictions for 1991-2002 were reasonably accurate (the mean percent error, i.e. root-mean-squared error/mean observed value, was $<5 \%$ ), the true cross-validated error value was most likely $<10 \%$. Nearly all the models had both the BHI and precipitation-day frequency as predictor variables, and the mean coefficient of determination for the models was 0.65 . 
Table 2. Climate data for the periods 1978-1980, 1996-1998, and 1973-2002 (data are means unless otherwise stated). LSF: last spring-freeze day; FFF: first fall-freeze day; FFP: frost-free period; $\Delta$ SOS: deviation from estimated typical start of growing season; DOY: day of year. Min. and Max. are minimum and maximum values for the variables, respectively

\begin{tabular}{|c|c|c|c|c|c|c|c|c|c|c|c|c|c|}
\hline \multirow[t]{2}{*}{ Period } & \multicolumn{3}{|c|}{$\begin{array}{l}\text { Daily solar radiation } \\
\left(\mathrm{Wh} \mathrm{m}^{-2}\right)\end{array}$} & \multicolumn{3}{|c|}{$\begin{array}{c}\text { Temperature } \\
\left({ }^{\circ} \mathrm{C}\right)\end{array}$} & \multicolumn{3}{|c|}{$\begin{array}{l}\text { Precipitation } \\
\text { (mm) }\end{array}$} & \multirow[t]{2}{*}{$\begin{array}{c}\text { LSF } \\
(\mathrm{DOY})\end{array}$} & \multirow[t]{2}{*}{$\begin{array}{c}\text { FFF } \\
(\mathrm{DOY})\end{array}$} & \multirow[t]{2}{*}{$\begin{array}{c}\text { FFP } \\
\text { (d) }\end{array}$} & \multirow[t]{2}{*}{$\begin{array}{c}\Delta \mathrm{SOS} \\
\quad(\mathrm{d})\end{array}$} \\
\hline & $\begin{array}{c}\text { Nov- } \\
\text { Oct }\end{array}$ & $\begin{array}{l}\text { Apr- } \\
\text { Oct }\end{array}$ & $\begin{array}{l}\text { Jun- } \\
\text { Jul }\end{array}$ & $\begin{array}{c}\text { Nov- } \\
\text { Oct }\end{array}$ & $\begin{array}{l}\text { Apr- } \\
\text { Oct }\end{array}$ & $\begin{array}{l}\text { Jun- } \\
\text { Jul }\end{array}$ & $\begin{array}{l}\text { Nov- } \\
\text { Oct }\end{array}$ & $\begin{array}{l}\text { Apr- } \\
\text { Oct }\end{array}$ & $\begin{array}{l}\text { Jun- } \\
\text { Jul }\end{array}$ & & & & \\
\hline $1978-1980$ & 4565 & 5577 & 6475 & 15.6 & 21.4 & 24.8 & 3.6 & 3.4 & 2.8 & 90 & 309 & 217 & +4 \\
\hline $1996-1998$ & 4569 & 5565 & 6354 & 15.7 & 21.1 & 24.9 & 4.0 & 3.5 & 3.4 & 94 & 306 & 211 & -4 \\
\hline $1973-2002$ & 4580 & 5574 & 6320 & 15.8 & 21.1 & 24.7 & 3.6 & 3.3 & 3.5 & 96 & 305 & 208 & 0 \\
\hline 1973-2002 (Min.) & 4284 & 5176 & 5472 & 14.8 & 20.1 & 23.0 & 2.7 & 2.3 & 1.5 & 83 & 284 & 181 & -28 \\
\hline 1973-2002 (Max.) & 4859 & 6001 & 7004 & 16.8 & 22.1 & 26.4 & 4.4 & 4.9 & 7.4 & 115 & 323 & 235 & +22 \\
\hline
\end{tabular}

Table 3. Preliminary and baseline net ecosystem production (NEP) values $\left(\mathrm{g} \mathrm{C} \mathrm{m}^{-2} \mathrm{yr}^{-1}\right)$ for land-cover classes in the Atlanta region. Baseline $\left(\mathrm{NEP}_{\mathrm{B}}\right)$ values are adjustments of preliminary values $\left(\mathrm{NEP}_{\mathrm{P}}\right)$ based on differences in growingseason length (GSL) between the Atlanta region and the 2 eddy-covariance sites (i.e. Walker Branch Watershed and Duke Forest)

\begin{tabular}{|lcc|}
\hline Land-cover class & $\mathrm{NEP}_{\mathrm{P}}$ & $\mathrm{NEP}_{\mathrm{B}}$ \\
\hline High-density urban & 0 & 0 \\
Low-density urban & 226 & 239 \\
Barren & 0 & 0 \\
Grass/crops & 65 & 65 \\
Forest & 551 & 622 \\
Water & 0 & 0 \\
\hline
\end{tabular}

\subsection{Carbon fluxes}

\subsubsection{Preliminary and baseline NEP}

The preliminary and baseline NEP values for the 6 land-cover classes were based on several assumptions (Table 3). The high-density urban, barren, and water classes had NEP values of zero. Although barren areas often have positive NEP values (i.e. net sources of $\mathrm{CO}_{2}$ ), most of the barren areas in the Atlanta region were rock rather than soil and bare soil was a transient phenomenon. The grassland/cropland NEP value was equal to the grassland NEP value at Duke Forest. The forest NEP value was the mean of the Walker Branch Watershed and Duke Forest NEP values. Finally, the low-density urban NEP value was a weighted combination; i.e. 43,34 , and $23 \%$ of the grassland, forest, and high-density urban NEP values, respectively.

The baseline NEP values (i.e. values adjusted for GSL) for the Atlanta region were at least $10 \%$ higher than the initial NEP values for some of the land-cover classes (Table 3). Since the mean annual temperature in the Atlanta region was $15.8^{\circ} \mathrm{C}$ - compared to $14.6^{\circ} \mathrm{C}$ at Duke Forest and $14.1^{\circ} \mathrm{C}$ at Walker Branch Watershed - the GSL for Atlanta was 6 and $9 \mathrm{~d}$ longer than the GSL at the 2 stations. Typical last spring-freeze dates near Duke Forest and Walker Branch Watershed were 7 and 9 d later (respectively) than at Atlanta; therefore, the above GSL adjustments were supported by other data. Only the forest NEP values were adjusted: the deciduous and coniferous forest NEP values increased to 705 and $541 \mathrm{~g} \mathrm{C} \mathrm{m}^{-2} \mathrm{yr}^{-1}$, respectively.

\subsubsection{UHI-based NEP adjustments}

Although 1978-1980 and 1996-1998 had similar regional climates, land-cover distributions differed greatly between the periods. The amount of forest land decreased from 61 to $50 \%$ of the domain in 1979 and 1997, respectively, and urbanization may have caused as much as a tripling in the amount of land significantly affected by the UHI between 1979 to 1997 (Fig. 4). Therefore, forest-to-urban conversion should have been the major control of NEP differences between the 2 periods.

The UHI was most likely responsible for NEP enhancement in the Atlanta region. Although UHIinduced increases in GSL could not offset the decreased NEP resulting from the loss of forests, the UHI adjustment did cause NEP to increase up to 4 and $12 \%$ over the NEP for Scenario 1 (i.e. no urban adjustment) for 1978-1980 and 1996-1998, respectively (Fig. 5). When only high-intensity urban land was assumed to contribute to an increased GSL, NEP did not increase; only when both types of urban land cover were considered did NEP increase. In fact, there was only a 5\% difference in NEP between 1978-1980 and 1996-1998 when Scenario 4 was used. Although forest area decreased by $\sim 1200 \mathrm{~km}^{2}$ (i.e. $\sim 20 \%$ ) between the 2 periods, an increase in mean NEP from 637 to $684 \mathrm{~g} \mathrm{C} \mathrm{m}^{-2} \mathrm{yr}^{-1}$ caused carbon sequestration by forests to only decrease by $\sim 13 \%$ (Fig. 6). Coincident with the change in forest NEP was a major increase in total NEP of low-intensity urban land; carbon sequestration by low-intensity urban lands increased by nearly $70 \%$ between the periods. 


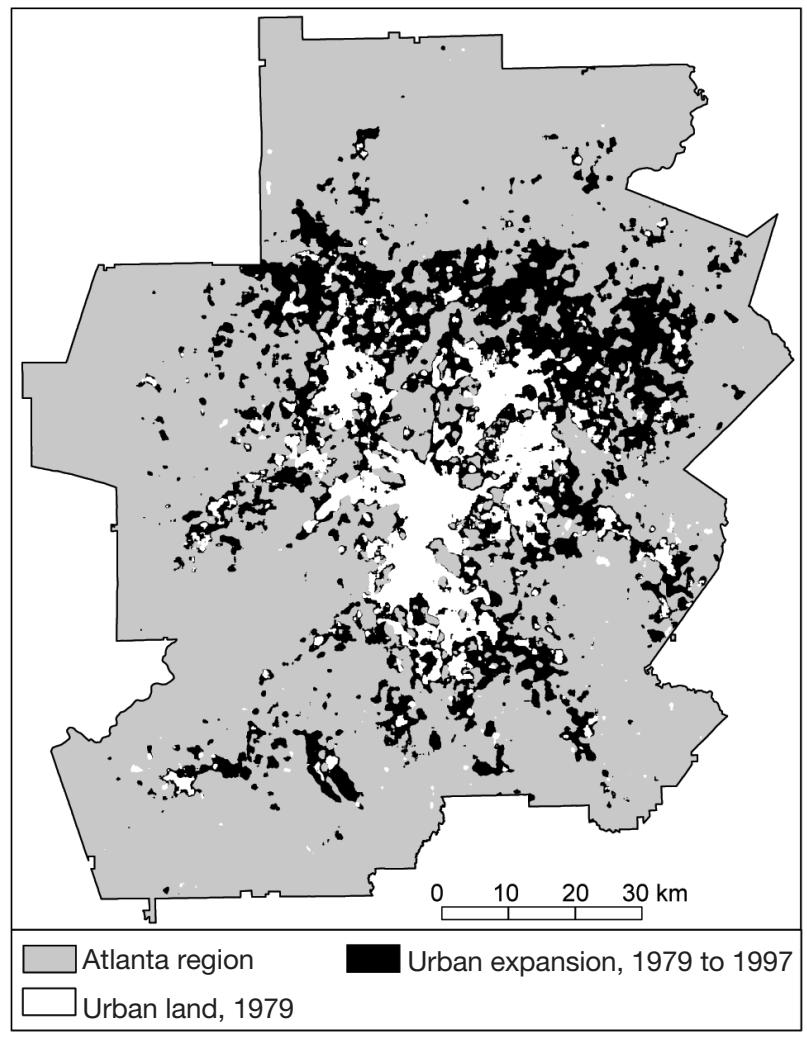

Fig. 4. Urban expansion within the Atlanta region from 1979 to 1997. Urban land includes both high-density and lowdensity urban land. The original land-cover data were coarsened to $1 \mathrm{~km}$ resolution using a majority filter

\subsubsection{Overall land-atmosphere carbon exchange}

When anthropogenic carbon emissions are considered, the Atlanta region was a net source of carbon in both 1978-1980 and 1996-1998. In less than $20 \mathrm{yr}$, anthropogenic carbon emissions more than doubled (i.e. $\sim 590 \mathrm{~g}$ to $\sim 1360 \mathrm{~g} \mathrm{C} \mathrm{m}^{-2} \mathrm{yr}^{-1}$ ). Therefore, net carbon emissions increased from $\sim 150 \mathrm{~g}$ in 1978-1980 to $\sim 940 \mathrm{~g} \mathrm{C} \mathrm{m}^{-2} \mathrm{yr}^{-1}$ in 1996-1998. Without considering the positive effects of the UHI on vegetation growth, the net carbon emissions in 1996-1998 would have been $\sim 990 \mathrm{~g} \mathrm{C} \mathrm{m}^{-2} \mathrm{yr}^{-1}$. Therefore, the increased GSL from the UHI probably only reduced the carbon-source strength of the Atlanta region by $\sim 5 \%$.

\section{DISCUSSION}

Since this study has used annual NEE values at several eddy-covariance sites in the southeastern USA to estimate annual NEP for the Atlanta region, the result is a useful approximation of biosphereatmosphere carbon exchange within the region. Results from this study indicate that, for a given plot of land,

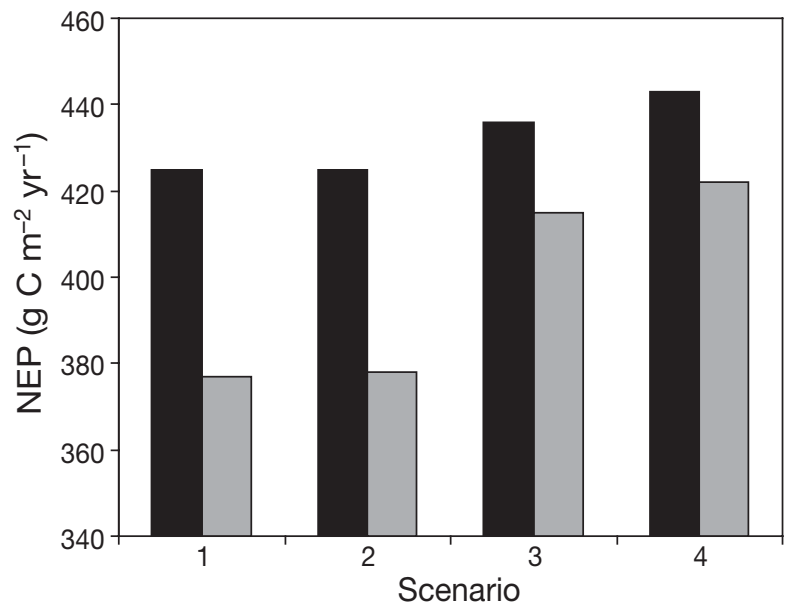

Fig. 5. Annual net ecosystem production for (NEP) 1978-1980

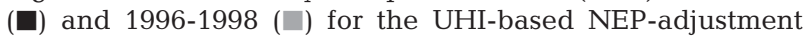
scenarios. See Table 1 for scenario description

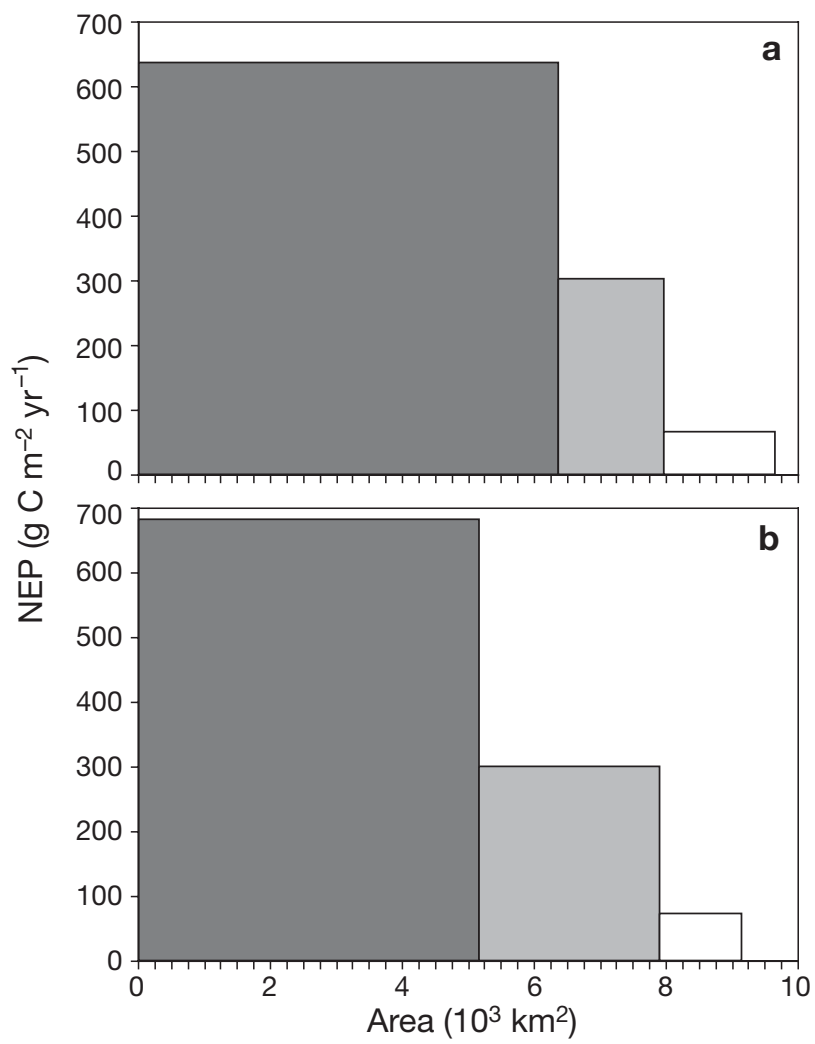

Fig. 6. Area and annual net ecosystem production (NEP) of forest $(\square)$, low-intensity urban land $(\square)$, and grass/crops $(\square)$ under Scenario 4 for (a) 1978- 1980 and (b) 1996-1998. See Table 1 for scenario description

changes in vegetative cover alone resulting from forestto-urban conversion probably decrease NEP by at least $60 \%$. Nevertheless, it is possible that urbanizationinduced increases in GSL reduce the NEP decrease.

No other NEP or NEE studies exist to validate the results of this study. Nevertheless, several studies did 
examine urbanization impacts on NPP during the late 1990s in the southeastern USA. Using nighttime satellite imagery, satellite-derived vegetation indices, and vegetation-based land-cover databases, both Milesi et al. (2003) and Imhoff et al. (2004) estimated that the urbanization of a tract of land in the southeastern USA reduces annual NPP by $\sim 20 \%$. The forest and urban NPP values presented in Milesi et al. (2003) were 1080 and $848 \mathrm{~g} \mathrm{C} \mathrm{m}^{-2} \mathrm{yr}^{-1}$, respectively, while the rural and urban NPP values presented in Imhoff et al. (2004) were 496 and $401 \mathrm{~g} \mathrm{C} \mathrm{m}^{-2} \mathrm{yr}^{-1}$, respectively. The employment of coarse resolution (i.e. 1 to $2.7 \mathrm{~km}$ ) spatial data almost certainly caused Milesi et al. (2003) and Imhoff et al. (2004) to overestimate the amount of urban land in the southeastern USA. As a result, much of the urban land in those studies was actually forest, and thus the urban NPP values were inflated. By taking a stratified sample of trees within approximately $200 \times 0.04$ ha plots within the city of Atlanta, Nowak \& Crane (2002) produced a tree-only biometric estimate of $123 \mathrm{~g} \mathrm{C} \mathrm{m}^{-2} \mathrm{yr}^{-1}$ for urban NPP. Using the forest and non-urban NPP values from Milesi et al. (2003) and Imhoff et al. (2004) and the urban NPP value from Nowak \& Crane (2002), forest-to-urban conversion leads to approximately a 75 to $90 \%$ decrease in NPP. Consequently, results presented in this study are partially supported by results from other studies.

The major deficiency of this study was the unknown accuracy of the NEP estimates for all the land-cover classes, especially forest, grass/crops, and low-density urban areas, within the Atlanta region. While the NEE values for forests at Walker Branch Watershed and Duke Forest can be assumed to be accurate, it is not known if those values should be applied to forested areas within the Atlanta region. Moreover, the GSLbased NEE adjustment for coniferous forests may have been considerably different from the true adjustment. Vegetation characteristics (e.g. composition, density, and age) are not uniform across forested patches in the Atlanta region. There is the possibility that the physical characteristics of forested patches in the Atlanta region, especially patches in residential areas, are not similar enough to the forests at Walker Branch Watershed and Duke Forest to warrant a transfer of NEE values. From 1973 to 2002, at least $20 \%$ of the Atlanta region was covered with grass or crops; however, only a single grassland NEE value obtained from Duke Forest from a single year was applied to the grass/ crops land-cover class. There is much variability among NEP values for grass and crops: annual grassland and cropland NEP values reported in Falge et al. (2002b) ranged from -212 to $538 \mathrm{~g}$ and from -115 to $588 \mathrm{~g} \mathrm{Cm}^{-2}$ $\mathrm{yr}^{-1}$, respectively. Finally, the uncertainties for the forest and grassland areas become increasingly more important when low-density urban land-which is approximately $34 \%$ forest and $43 \%$ grass - is considered. Coverage of the Atlanta region by low-density urban land increased from 12 to $29 \%$ from 1973 to 2002. Urban forests tend to have half the tree density of rural forests (Nowak \& Crane 2002). Therefore, NEE for urban forests directly impacted by human activities could be considerably different from NEE for rural forests in the same region.

If one accepts the major finding of a slight decrease in domain-wide NEP from 1978-1980 to 1996-1998, then we can reasonably assume that there was no change in NEP between the periods. In addition to the UHI impact on NEP, increased anthropogenic contributions of carbon and nitrogen to the environment may have helped increase domain-wide NEP. Along with an increase in mean annual background $\mathrm{CO}_{2}$ concentrations in the Northern Hemisphere from 337 ppm in 1979 to $364 \mathrm{ppm}$ in 1997 (Keeling \& Whorf 2005), anthropogenic carbon emissions in the Atlanta region more than doubled over that time period. Based on findings in Gregg et al. (2003) and Ziska et al. (2004) for urban areas in the eastern USA, mean annual $\mathrm{CO}_{2}$ concentrations in 1997 probably exceeded $400 \mathrm{ppm}$ in the urbanized areas of the Atlanta region. Moreover, anthropogenic $\mathrm{NO}_{\mathrm{x}}$ emissions within the region and proximate to the western edge of the region (i.e. upwind power plants) exceeded $0.3 \mathrm{Tg} \mathrm{yr}^{-1}$ in 1997; this was at least a $10 \%$ increase over 1979 emissions. As a result, much of the Atlanta region may have had nitrogen-deposition rates that were at least twice as high as background rates (US EPA 2002). In addition, $>75 \%$ of homeowners in Georgia apply nitrogen fertilizer to their landscapes (e.g. lawns, trees, etc.) (Varlamoff et al. 2001). This is important, because NPP of forests in the southeastern USA is limited by the availability of nitrogen (Finzi et al. 2004). Even without modifying soil-nitrogen levels, Oren et al. (2001) found NPP at a $\mathrm{CO}_{2}$-enriched (i.e. $550 \mathrm{ppm}$ ) coniferous forest site at Duke Forest to be $7 \%$ larger than NPP at a site without $\mathrm{CO}_{2}$-enrichment. For the Atlanta region, if it is assumed that $\mathrm{CO}_{2}$ fertilization increased both spatially and in magnitude in 1997 compared to 1979, then the domainwide NEP in 1997 was equivalent to, or exceeded, the domain-wide NEP in 1979. Although diffuse PAR over that time period may have increased (e.g. there was a $7 \%$ increase in $\mathrm{PM}_{10}$ emissions from 1985 to 1997) thereby possibly enhancing photosynthesis, the Atlanta region during the growing season had considerable cloud cover, which might cancel the positive effects of urban aerosols on photosynthesis (Cohan et al. 2002). Ozone may damage vegetation, but there was no significant trend in ground ozone levels in the Atlanta region from 1980 to 1998 (Lin et al. 2001), and it is not known if any trees in the Atlanta region have been noticeably damaged from ozone exposure (Styers 2005). 


\section{CONCLUSIONS}

Urbanization is capable of dramatically impacting land-atmosphere exchanges of gases, including greenhouse gases. This study examined the impact of urban expansion on land-atmosphere carbon exchange within the Atlanta region. This was achieved primarily by establishing baseline NEP values for landcover classes within the region and then quantitatively and qualitatively assessing the direct and indirect impacts of multi-decadal land-cover change on NEP. In addition, temporal changes in net carbon exchange (i.e. anthropogenic carbon emissions minus NEP) were estimated. Results from this study indicate that the net effect of urban expansion was to greatly increase the carbon emissions of the Atlanta region.

Although urban expansion causes dramatic increases in anthropogenic carbon emissions, this need not significantly alter region-wide NEP. From 1978-1980 to 1996-1998, the forest land-cover decreased from over 60 to $\sim 50 \%$ of the region. Possibly countering the above negative effect of urbanization on NEP are the positive effects of a longer growing season from an intensified and expanded UHI and increased fertilization from nitrogen and carbon dioxide. Thus, similar NEP values might occur in the future during sets of years with climatic conditions similar to that of 19781980 and 1996-1998.

To obtain better estimates of NEP, intensive ecological inventorying based on detailed land-cover databases is needed. This procedure would generate multitemporal estimates of NEP, thereby accounting for the impacts of climatic variability at multiple spatial scales on NEP. Finally, urbanization-based NEP studies are needed in the many different types of growing metropolitan areas around the world. Results from studies in the Atlanta region are not necessarily transferable to metropolitan areas outside the southeastern USA; nonetheless, Atlanta-based studies offer important insights into the impacts of urbanization on land-atmosphere carbon exchange.

\section{LITERATURE CITED}

Aikawa M, Yoshikawa K, Tomida M, Aotsuka F, Haraguchi H (1995) Continuous monitoring of carbon dioxide concentration in the urban atmosphere of Nagoya, 1991-1993. Anal Sci 11:357-362

Baldocchi D, Valentini R, Running S, Oechel W, Dahlman R (1996) Strategies for measuring and modelling carbon dioxide and water vapour fluxes over terrestrial ecosystems. Global Change Biol 2:159-168

Barford CC, Wofsy SC, Goulden ML, Munger JW and 6 others (2001) Factors controlling long- and short-term sequestration of atmospheric $\mathrm{CO}_{2}$ in a mid-latitude forest. Science 294:1688-1691

Cohan DS, Xu J, Greenwald R, Bergin MH, Chameides WL
(2002) Impact of atmospheric aerosol light scattering and absorption on terrestrial net primary productivity. Global Biogeochem Cycles 16:1090 (Art. no.)

Curtis PS, Hanson PJ, Bolstad P, Barford C, Randolph JC, Schmid HP, Wilson KB (2002) Biometric and eddycovariance based estimates of annual carbon storage in five eastern North American deciduous forests. Agric For Meteorol 113:3-19

Davidson EA, Belk E, Boone RD (1998) Soil water content and temperature as independent factors controlling soil respiration in a temperate mixed hardwood forest. Global Change Biol 4:217-226

Erlick C, Frederick JE (1998) Effects of aerosols on the wavelength dependence of atmospheric transmission in the ultraviolet and visible. II. Continental and urban aerosols in clear skies. J Geophys Res D 103:23275-23285

Falge E, Tenhunen J, Baldocchi D, Aubinet M and 36 others (2002a) Phase and amplitude of ecosystem carbon release and uptake potentials as derived from FLUXNET measurements. Agric For Meteorol 113:75-95

Falge E, Baldocchi D, Tenhunen J, Aubinet M and 28 others (2002b) Seasonality of ecosystem respiration and gross primary production as derived from FLUXNET measurements. Agric For Meteorol 113:53-74

Felzer B, Kicklighter D, Melillo J, Wang C, Zhuang O, Prinn R (2004) Effects of ozone on net primary production and carbon sequestration in the conterminous United States using a biogeochemistry model. Tellus B 56:230-248

Fenn ME, Haeuber R, Tonnesen GS, Baron JS and 7 others (2003) Nitrogen emissions, deposition, and monitoring in the western United States. Bioscience 53:391-403

Finzi AC, DeLucia EH, Sclesinger WH (2004) Canopy N and P dynamics of a southeastern US pine forest under elevated $\mathrm{CO}_{2}$. Biogeochemistry 69:363-378

Friedlingstein P, Fung I, Holland E, John J, Brasseur G, Erickson D, Schimel D (1995) On the contribution of $\mathrm{CO}_{2}$ fertilization to the missing biospheric sink. Global Biogeochem Cycles 9:541-556

Goulden ML, Munger JW, Fan SM, Daube BC, Wofsy SC (1996) Exchange of carbon dioxide by a deciduous forest: response to interannual climate variability. Science 271: $1576-1578$

Gratani L, Varone L (2005) Daily and seasonal variation of $\mathrm{CO}_{2}$ in the city of Rome in relationship with the traffic volume. Atmos Environ 39:2619-2624

Gregg JW, Jones CG, Dawson TE (2003) Urbanization effects on tree growth in the vicinity of New York City. Nature 424:183-187

Grimmond CSB, King TS, Cropley FD, Nowak DJ, Souch C (2002) Local-scale fluxes of carbon dioxide in urban environments: methodological challenges and results from Chicago. Environ Pollut 116:S243-S254

Grimmond CSB, Salmond JA, Oke TR, Lemonsu A (2004) Flux and turbulence measurements at a densely built-up site in Marseille: heat, mass (water and carbon dioxide), and momentum. J Geophys Res D 109:D24101

Groffman PM, Law NL, Belt KT, Band LE, Fisher GT (2004) Nitrogen fluxes and retention in urban watershed ecosystems. Ecosystems 7:393-403

Hamilton JG, DeLucia EH, George K, Naidu SL, Finzi AC, Schlesinger WH (2002) Forest carbon balance under elevated $\mathrm{CO}_{2}$. Oecologia 131:250-260

Henderson KG, Vega AJ (1996) Regional precipitation variability in the southeastern United States. Phys Geogr 17: 93-112

Hunter AF, Lechowicz MJ (1992) Predicting the timing of budburst in temperate trees. J Appl Ecol 29:597-604 
Idso CD, Idso SB, Balling RC (2001) An intensive two-week study of an urban $\mathrm{CO}_{2}$ dome in Phoenix, Arizona, USA. Atmos Environ 35:995-1000

Imhoff ML, Bounoua L, DeFries R, Lawrence WT, Stutzerd D, Tucker CJ, Ricketts T (2004) The consequences of urban land transformation on net primary productivity in the United States. Remote Sens Environ 89:434-443

IPCC (Intergovernmnetal Panel on Climate Change) (2001) Climate change 2001: the scientific basis. Cambridge University Press, Cambridge

Jacovides CP, Timbios F, Asimakopoulos DN, Steven MD (1997) Urban aerosol and clear skies spectra for global and diffuse photosynthetically active radiation. Agric For Meteorol 87:91-104

Kalnay E, Kanamitsu M, Kistler R, Collins W and 18 others (1996) The NCEP/NCAR 40-year reanalysis project. Bull Am Meteorol Soc 77:437-471

Keeling CD, Whorf TP (2005) Atmospheric $\mathrm{CO}_{2}$ records from sites in the SIO air sampling network. In: Trends: a compendium of data on global change. Carbon Dioxide Information Analysis Center, Oak Ridge National Laboratory, US Department of Energy, Oak Ridge, TN

Koerner B, Klopatek J (2002) Anthropogenic and natural $\mathrm{CO}_{2}$ emission sources in an arid urban environment. Environ Pollut 116:S45-S51

Kuc T, Rozanski K, Zimnoch M, Necki JM, Korus A (2003) Anthropogenic emissions of $\mathrm{CO}_{2}$ and $\mathrm{CH}_{4}$ in an urban environment. Appl Energy 75:193-203

Lai CT, Katul G, Butnor J, Ellsworth D, Oren R (2002) Modelling night-time ecosystem respiration by a constrained source optimization method. Global Change Biol 8:124-141

Lin CY, Jacob DJ, Fiore AM (2001) Trends in exceedances of the ozone air quality standard in the continental United States, 1980-1998. Atmos Environ 35:3217-3228

Lovett GM, Traynor MM, Pouyat RV, Carreiro MM, Zhu WX, Baxter JM (2000) Atmospheric deposition to oak forests along an urban-rural gradient. Environ Sci Technol 34: 4294-4300

Michaels PJ, Knappenberger PC, Balling RC, Davis RE (2000) Observed warming in cold anticyclones. Clim Res 14: $1-6$

Milesi C, Elvidge CD, Nemani RR, Running SW (2003) Assessing the impact of urban land development on net primary productivity in the southeastern United States. Remote Sens Environ 86:401-410

Misson L, Lunden M, McKay M, Goldstein AH (2005) Atmospheric aerosol light scattering and surface wetness influence the diurnal pattern of net ecosystem exchange in a semi-arid ponderosa pine plantation. Agric For Meteorol 129:69-83

Moriwaki R, Kanda M (2004) Seasonal and diurnal fluxes of radiation, heat, water vapor, and carbon dioxide over a suburban area. J Appl Meteorol 43:1700-1710

Myneni RB, Keeling CD, Tucker CJ, Asrar G, Nemani RR (1997) Increased plant growth in the northern high latitudes from 1981-1991. Nature 386:698-702

Nemani RR, Keeling CD, Hashimoto H, Jolly WM, Piper SC, Tucker CJ, Myneni RB, Running SW (2003) Climatedriven increases in global terrestrial net primary production from 1982 to 1999. Science 300:1560-1563

Nemitz E, Hargreaves KJ, McDonald AG, Dorsey JR, Fowler D (2002) Micrometeorological measurements of the urban heat budget and $\mathrm{CO}_{2}$ emissions on a city scale. Environ Sci Technol 36:3139-3146

Novak K, Schaub M, Fuhrer J, Skelly JM, Hug C, Landolt W, Bleuler P, Kräuchi N (2005) Seasonal trends in reduced leaf gas exchange and ozone-induced foliar injury in three ozone sensitive woody plant species. Environ Pollut 136: $33-45$

Novik KA, Story PC, Katul GG, Ellsworth DS, Siqueira MBS, Juang J, Oren R (2004) Carbon dioxide and water vapor exchange in a warm temperate grassland. Oecologia 138: 259-274

Nowak DJ, Crane DE (2002) Carbon storage and sequestration by urban trees in the USA. Environ Pollut 116: 381-389

Oke TR (1987) Boundary layer climates. Methuen, London

Oren R, Ellsworth DS, Johnsen KH, Phillips N and 7 others (2001) Soil fertility limits carbon sequestration by forest ecosystems in a $\mathrm{CO}_{2}$-enriched atmosphere. Nature 411: 469-472

Pataki DE, Bowling DR, Ehleringer JR (2003) Seasonal cycle of carbon dioxide and its isotopic composition in an urban atmosphere: anthropogenic and biogenic effects. J Geophys Res D 108:4735 (Art. no.)

Robeson SM (2002) Increasing growing-season length in Illinois during the 20th century. Clim Change 52:219-238

Roderick ML, Farquhar GD, Berry SL, Noble IR (2001) On the direct effect of clouds and atmospheric particles on the productivity and structure of vegetation. Oecologia 129: 21-30

Schäfer KVR, Oren R, Ellsworth DS, Lai CT, Herrick JD, Finzi AC, Richter DD, Katul GG (2003) Exposure to an enriched $\mathrm{CO}_{2}$ atmosphere alters carbon assimilation and allocation in a pine forest ecosystem. Global Change Biol 9:1378-1400

Schmid HP (1994) Source areas for scalars and scalar fluxes. Boundary-Layer Meteorol 67:293-318

Schmid HP, Su HB, Vogel CS, Curtis PS (2003) Ecosystematmosphere exchange of carbon dioxide over a mixed hardwood forest in northern lower Michigan. J Geophys Res D 108:4417-4435

Soegaard H, Møller-Jensen L (2003) Towards a spatial $\mathrm{CO}_{2}$ budget of a metropolitan region based on textural image classification and flux measurements. Remote Sens Environ 87:283-294

Stahle DW, Cleaveland MK (1992) Reconstruction and analysis of spring rainfall over the southeastern U.S. for the past 1000 years. Bull Am Meteorol Soc 73:1947-1961

Styers DM (2005) Ozone damage potential to loblolly pine ecosystems in metropolitan Atlanta, Georgia. MA thesis, Georgia State University, Atlanta

Takagi M, Gyokusen K, Saito A (1998) Increase in the $\mathrm{CO}_{2}$ exchange rate of leaves of Ilex rotunda with elevated atmospheric $\mathrm{CO}_{2}$ concentration in an urban canyon. Int $\mathrm{J}$ Biometeorol 42:16-21

Takahashi HA, Hiyama T, Konohira E, Takahashi A, Yoshida N, Nakamura T (2001) Balance and behavior of carbon dioxide at an urban forest inferred from the isotopic and meteorological approaches. Radiocarbon 43:659-669

Townsend AR, Braswell BH, Holland EA, Penner JE (1996) Spatial and temporal patterns in terrestrial carbon storage due to deposition of fossil fuel nitrogen. Ecol Appl 6: 806-814

Trewartha GT, Horn LH (1980) An introduction to climate. McGraw-Hill, New York

US Census Bureau (2001) Census 2000: twenty-second census of population and housing. US Census Bureau, Washington, DC

US EPA (United States Environmental Protection Agency) (2002) Nitrogen: multiple and regional impacts. EPA-430R-01-006. US EPA, Washington, DC

US EPA (United States Environmental Protection Agency) (2004) The ozone report: measuring progress through 2003. EPA-454-K-04-001. US EPA, Research Triangle Park, NC 
Varlamoff S, Florkowski WJ, Jordan JL, Latimer J, Braman K (2001) Georgia homeowner survey of landscape management practices. Horttechnology 11:326-331

Vinnikov KY, Robock A, Stouffer RJ, Walsh JE and 5 others (1999) Global warming and northern hemisphere sea ice extent. Science 286:1934-1937

White MA, Thornton PE, Running SW (1997) A continental phenology model for monitoring vegetation responses to interannual climatic variability. Global Biogeochem Cycles $11: 217-234$

White MA, Running SW, Thornton PE (1999) The impact of growing-season length variability on carbon assimilation and evapotranspiration over 88 years in the eastern US deciduous forest. Int J Biometeorol 42:139-145

White MA, Nemani RR, Thornton PE, Running SW (2002) Satellite evidence of phenological differences between urbanized and rural areas of the eastern United

Editorial responsibility: Gregory V. Jones, Ashland, Oregon, USA
States deciduous broadleaf forest. Ecosystems 5:260-273 Wilbanks TJ, Kates RW (1999) Global change in local places: how scale matters. Clim Change 43:601-628

Wilson KB, Baldocchi DD (2001) Comparing independent estimates of carbon dioxide exchange over 5 years at a deciduous forest in the southeastern United States. J Geophys Res D 106:34167-34178

Yang X, Lo CP (2002) Using a time series of satellite imagery to detect land use and land cover changes in the Atlanta, Georgia metropolitan area. Int J Remote Sens 23:1775-1798

Zhang XY, Friedl MA, Schaaf CB, Strahler AH, Schneider A (2004) The footprint of urban climates on vegetation phenology. Geophys Res Lett 31: L12209 (Art. no.)

Ziska LH, Bunce JA, Goins EW (2004) Characterization of an urban-rural $\mathrm{CO}_{2}$ /temperature gradient and associated changes in initial plant productivity during secondary succession. Oecologia 139:454-458

Submitted: October 10, 2005; Accepted: March 13, 2006 Proofs received from author(s): April 8, 2006 